\title{
ARTIKELEN
}

\section{Verbintenisrechtelijke correctiemechanismen van het ongeoorloofd verrijkingsoogmerk van de bemiddelaar}

\author{
Matthias Meirlaen
}

Elke bemiddelaar moet op een onafhankelijke en onpartijdige wijze bemiddelen. Deze waarden behoren tot de kern van de bemiddeling. Wat als een bemiddelaar zichzelf evenwel probeert te verrijken? In deze bijdrage wordt hoofdzakelijk ingegaan op enkele verbintenisrechtelijke correctiemechanismen. Concreet wordt (i) het verbod van rechtsmisbruik, (ii) het vereiste van een rechtmatig belang, (iii) het adagium fraus omnia corrumpit, (iv) het wilsgebrek bedrog en (v) de ongeoorloofde oorzaak als geldigheidsvereiste toegelicht aan de hand van de rechtspraak van het Belgische Hof van Cassatie.

\section{Inleiding}

Bemiddeling wordt in artikel 1723/1 van het Belgisch Gerechtelijk Wetboek omschreven als 'een vertrouwelijk en gestructureerd proces van vrijwillig overleg tussen conflicterende partijen met de medewerking van een onafhankelijke, neutrale en onpartijdige derde die de communicatie vergemakkelijkt en poogt de partijen ertoe te brengen zelf een oplossing uit te werken'. ${ }^{1}$ De Belgische regeling is toegespitst op conflictbemiddeling. ${ }^{2}$

Eenieder kan in principe optreden als bemiddelaar, zij het dat de wetgever naargelang de materie waarover wordt bemiddeld en het beroepsmatig karakter van de bemiddeling een sterke voorkeur heeft voor de erkend bemiddelaar. ${ }^{3}$ Wie beroepsmatig wil bemiddelen in andere geschillen dan tussen ondernemingen, moet erkend zijn als 'erkend bemiddelaar'. ${ }^{4}$ Om erkend te worden, moet de bemiddelaar onder meer geslaagd zijn voor de opleiding, de noodzakelijke waarborgen inzake onafhankelijkheid, neutraliteit en onpartijdigheid bieden en de deontologische code naleven. ${ }^{5}$ Een erkenning is momenteel niet vereist voor

1 Art. 1723/1 Gerechtelijk Wetboek 10 oktober 1967, BS 31 oktober 1967 (hierna Ger.W.).

2 Voor de vele ladingen die 'bemiddeling' dekt, zie bijv. D. Evers, Ontwikkelingsgericht bemiddelen. Conflicten als bron van groei, TMD 2010, nr. 3, p. 9-17.

3 Zie bijv. MvT bij wetsontontwerp houdende diverse bepalingen inzake burgerlijk recht en houdende wijziging van het Gerechtelijk Wetboek met het oog op de bevordering van alternatieve vormen van geschillenoplossing, Parl.St. Kamer 2017-18, nr. 2919/001, 55-56.

$4 \quad$ Art. 227quater Strafwetboek 8 juni 1867, BS 9 juni 1867 (hierna Sw.).

5 Art. 1726 Ger.W. 
het niet-beroepsmatig bemiddelen of het beroepsmatig bemiddelen in geschillen tussen ondernemingen. ${ }^{6}$

Elke bemiddelaar moet op een onafhankelijke en onpartijdige wijze bemiddelen. Deze waarden behoren tot de kern van bemiddeling. ${ }^{7}$ De onafhankelijkheid houdt onder meer in dat de bemiddelaar vrij is om in het belang van alle betrokken partijen te handelen. Een partij kan niet (on)rechtstreeks de bemiddelaar onder druk zetten. De onpartijdigheid verwijst naar de mogelijkheid om op een neutrale wijze te bemiddelen tussen partijen, dat wil zeggen zonder persoonlijke belangen, voorkeur of afkeur. De bemiddelaar moet zich boven het conflict plaatsen. ${ }^{8}$

Voor de erkend bemiddelaar schrijft de deontologische code van de Federale Bemiddelingscommissie uitdrukkelijk voor dat de erkend bemiddelaar de plicht heeft om de onafhankelijkheid en de onpartijdigheid, die onlosmakelijk verbonden zijn met zijn functie, te waarborgen, en niet mag tussenkomen wanneer hij, omwille van persoonlijke materiële of morele belangen, zijn functie niet kan vervullen in onafhankelijkheid en onpartijdigheid. De erkend bemiddelaar mag bijvoorbeeld niet bemiddelen indien hij een persoonlijke of zakelijke relatie heeft met één van de partijen of indien hij rechtstreeks of onrechtstreeks voordelen kan halen uit het resultaat. Indien een schijn van gebrek aan onafhankelijkheid en onpartijdigheid bestaat of ontstaat, zal de bemiddelaar zowel voorafgaandelijk als tijdens de bemiddeling melding maken aan partijen van de elementen die kunnen worden geacht zijn onafhankelijkheid of onpartijdigheid in het gedrang te brengen. Hierna heeft de bemiddelaar twee mogelijkheden: ofwel trekt hij zich terug uit de bemiddeling, ofwel bekomt hij van de partijen een akkoord om de bemiddeling voort te zetten. ${ }^{9}$

6 Art. 227quater Sw. Weliswaar zou voor de toepassing van het Gerechtelijk Wetboek onder bemiddelaar een erkend bemiddelaar moeten worden verstaan (art. 1726, § 1/1 Ger.W.) en moet de rechter bij gerechtelijke bemiddeling nagaan of de door partijen voorgedragen bemiddelaar beantwoordt aan de erkenningscriteria (art. 1734, § 1/1 Ger.W.). Over het inconsistent optreden van de wetgever, zie bijv. T. Wijnant, Alternatieve geschillenoplossing in familiezaken na de wetten van 15 en 18 juni 2018, T.Fam. 2019, afl. 5, 112-121 en verwijzingen aldaar.

7 Art. 1723/1 Ger.W. Terecht wordt in de rechtsleer opgemerkt dat de bemiddelaar een meerwaarde kan bieden door op vraag van partijen een evenwichtig voorstel voor te leggen, zie bijv. T. Wijnant, Alternatieve geschillenoplossing in familiezaken na de wetten van 15 en 18 juni 2018, T.Fam. 2019, afl. 5, 112-114.

8 De onafhankelijkheid en de onpartijdigheid zijn met elkaar verbonden waarden. Wanneer een partij bijvoorbeeld in staat is om druk uit te oefenen op de bemiddelaar, dan is de kans ook groot dat de bemiddelaar partijdig is. Zie ook E. Lancksweerdt, Bemiddeling, in: Conflictafhandeling buiten de rechtbank, Mortsel: Intersentia 2019, p. 243, 265-266; T. De Beir, De nieuwe bemiddelingswet doorgrond, in: Conflictafhandeling buiten de rechtbank, Mortsel: Intersentia 2019, p. 287, 319-320.

9 Art. 4-6 Deontologische code. Zie hiervoor Beslissing van 18 oktober 2007 betreffende de gedragscode van de erkende bemiddelaar. De deontologische regels maken deel uit van de verhouding tussen de erkend bemiddelaar en de partijen. De partijen mogen er rechtmatig op vertrouwen dat de erkend bemiddelaar de deontologische code naleeft. De erkend bemiddelaar heeft zich verbonden tot de naleving van de deontologische code via eenzijdige wilsuiting. Cf. Cass. 9 mei 1980, Arr.Cass. 1979-80, 1139. Daar veel deontologische regels een herhaling of een concretisering vormen van wettelijk opgelegde kernwaarden van bemiddeling, gaat van deze regels ook een zekere reflexwerking uit naar de inkleuring van de verhouding tussen de niet-erkend bemiddelaar en de partijen. 
De bemiddelaar moet de partijen informeren over elk mogelijk gebrek aan onafhankelijkheid of onpartijdigheid, ook al denkt de bemiddelaar dat hij op een onafhankelijke en onpartijdige wijze kan bemiddelen. Het zijn de partijen die oordelen of de bemiddelaar zijn rol op een onafhankelijke en onpartijdige wijze kan vervullen. Het gevaar bestaat immers dat een partij een gebrek aan onafhankelijkheid of onpartijdigheid ontdekt en haar vertrouwen in de bemiddelaar en het bemiddelingstraject verliest.

De niet-naleving van de plicht tot transparantie over elk mogelijk gebrek aan onafhankelijkheid of onpartijdigheid, dan wel de plicht tot onafhankelijkheid en onpartijdigheid zelf, kan leiden tot de beëindiging van de bemiddeling en de aansprakelijkheid van de bemiddelaar voor de daardoor veroorzaakte schade (bijv. gemaakte kosten). ${ }^{10}$ De erkend bemiddelaar kan daarenboven een sanctie worden opgelegd door de commissie voor tuchtregeling en klachtenbehandeling, zoals een berisping, een schorsing of zelfs een intrekking van zijn erkenning. ${ }^{11}$

Een typegeval van een inbreuk op de verplichting tot onafhankelijkheid en onpartijdigheid is de bemiddelaar die zichzelf op een ongeoorloofde wijze probeert te verrijken. $^{12}$

Een bemiddelaar mag een vergoeding vragen voor zijn tussenkomst. De omvang van de bemiddelingsvergoeding bepaalt de bemiddelaar in eerste instantie zelf. Er zijn tot op heden in het Belgische recht geen regels die de bemiddelaar daarbij richting geven. ${ }^{13}$ Hij zal partijen wel vooraf moeten informeren over de bemiddelingsvergoeding en/of de wijze waarop hij de vergoeding zal bepalen. ${ }^{14}$ De bemid-

10 De precontractuele informatieplicht vloeit voort uit de artikelen 1382-1383 Burgerlijk Wetboek 21 maart 1804, BS 3 september 1807 (hierna BW). Een contractuele informatieplicht vloeit voort uit art. 1134, lid 3 BW (aanvullende werking van de goede trouw). Elke partij kan te allen tijde een einde kan maken aan de bemiddeling, zonder dat dit tot haar nadeel kan strekken (art. 1729 Ger.W.). Zie ook art. 7 Deontologische code.

11 Art. 1727/5, § 4 Ger.W.

12 Cf. Antwerpen 22 oktober 2019, nr. 2018/AR/1500 en 2018/AR/1503, onuitg. Een man zet een buurvrouw aan om beroep aan te tekenen tegen de vergunning tot het oprichten van een winkelcomplex om zo de projectontwikkelaar onder druk te kunnen zetten en hieruit munt te slaan. De projectontwikkelaar koopt door de tussenkomst van de man de woning van de buurvrouw tegen een hoge prijs en is aan de man een 'bemiddelingsvergoeding' van $€ 100.000$ verschuldigd. Het hof van beroep te Antwerpen stelt dat de beroepsprocedure tegen de vergunning wordt misbruikt, daar de beroepsprocedure duidelijk een louter financieel doel beoogt (los van elke stedenbouwkundige finaliteit). Vervolgens verklaart het hof de 'bemiddelingsovereenkomst' nietig wegens een ongeoorloofde oorzaak. De man probeerde zich immers via de beroepsprocedure te verrijken 'hetgeen ingaat tegen de openbare orde en de goede zeden, te meer daar [de man] een (voormalig) gemeenteraadslid is, die persoonlijk failliet is verklaard en geen bemiddelaar is'.

13 Voor andere beroepsactiviteiten worden de regels soms bijzonder vaag omschreven. Voor de advocaat, zie bijv. art. 446ter Ger.W.: 'De advocaten begroten hun ereloon met de bescheidenheid die van hun functie moet worden verwacht. [...] Ingeval het ereloon niet met een billijke gematigdheid is vastgesteld, wordt het door de raad van de Orde verminderd, met inachtneming onder meer van de belangrijkheid van de zaak en van de aard van het werk, onder voorbehoud van de teruggave die hij beveelt, indien daartoe grond bestaat, dit alles onverminderd het recht van de partij om zich tot het gerecht te wenden indien de zaak niet aan een scheidsgerecht is onderworpen.'

14 Deze afspraken moeten worden opgenomen in het bemiddelingsprotocol. Zie art. 1731, § 2, $6^{\circ}$ Ger.W. Voor de erkend bemiddelaar, zie ook art. 17-18 Deontologische code. 
delingskosten en het ereloon van de bemiddelaar worden tussen partijen gelijk verdeeld, tenzij zij daarover anders beslissen. ${ }^{15}$

Een bemiddelaar mag winst nastreven, ${ }^{16}$ maar hij mag zichzelf niet op een ongeoorloofde wijze proberen te verrijken. De opdracht van de bemiddelaar bestaat er immers in om op een onafhankelijke en onpartijdige wijze de partijen tot een oplossing te brengen. Dit moet het hoofddoel van de bemiddelaar zijn. Of een bemiddelaar zich daadwerkelijk op een ongeoorloofde wijze probeert te verrijken, zal afhangen van de concrete omstandigheden. Gezichtspunten van een ongeoorloofd verrijkingsoogmerk vormen bijvoorbeeld de enorme omvang van de bemiddelingsvergoeding, de geringe omvang van de geleverde inspanningen en het bestaan van contacten tussen een partij en de bemiddelaar of een met hem verbonden (rechts)persoon vóór het ontstaan van het conflict. ${ }^{17}$

\section{Verbintenisrechtelijke correctiemechanismen}

Wanneer de bemiddelaar zichzelf op een ongeoorloofde wijze probeert te verrijken, voorziet het verbintenissenrecht in meerdere correctiemechanismen. De correctie kan onder meer betrekking hebben op de bemiddelingsvergoeding, de bemiddelingsovereenkomst en/of de overeenkomst die het gevolg is van de bemiddeling. De correctie vindt toepassing, ongeacht de vraag of de bemiddelaar erkend is. ${ }^{18}$ Concreet wordt ingegaan op (i) het verbod van rechtsmisbruik, (ii) het vereiste van een rechtmatig belang, (iii) het adagium fraus omnia corrumpit, (iv) het wilsgebrek bedrog, en (v) de ongeoorloofde oorzaak als geldigheidsvereiste. Deze correctiemechanismen worden uiteengezet aan de hand van de rechtspraak van het Belgische Hof van Cassatie.

\section{Verbod van rechtsmisbruik}

Een overeenkomst strekt partijen tot wet, maar zij moet te goeder trouw worden uitgevoerd. ${ }^{19}$ Volgens het Hof van Cassatie voert een partij de overeenkomst niet te goeder trouw uit, wanneer is vastgesteld dat zij haar recht heeft misbruikt. ${ }^{20}$ Rechtsmisbruik bestaat volgens het Hof in 'de uitoefening van een recht op een wijze die kennelijk de grenzen te buiten gaat van de uitoefening van dat recht door een bedachtzaam en voorzichtig persoon' ${ }^{21}$ Het Hof heeft het algemeen criterium van kennelijke grensoverschrijdende rechtsuitoefening al iets concreter gemaakt door te verduidelijken dat een subjectief recht niet mag worden uitge-

16 De mogelijkheid om winst na te streven staat los van de erkenning als bemiddelaar of het beroepsmatige karakter van het optreden als bemiddelaar.

17 Zie ook art. 5 Deontologische code: 'De bemiddelaar mag niet bemiddelen in een conflict waarbij hij rechtstreeks of onrechtstreeks voordelen kan halen uit het resultaat.'

18 Bij een erkend bemiddelaar kan een partij ook een klacht indienen bij de commissie voor de tuchtregeling en klachtenbehandeling (art. 1727/5, § 2 Ger.W.).

19 Art. 1134, lid 1 en 3 BW.

20 Zie Cass. 13 maart 1998, AR C.97.0050.F; Cass. 17 mei 1990, Arr. Cass. 1989-90, 1188.

21 Zie bijv. Cass. 19 december 2019, AR C.19.0127.N; Cass. 3 februari 2017, AR C.16.0055.N. 
oefend (i) met het exclusief oogmerk tot schaden, ${ }^{22}$ (ii) op de meest schadelijke wijze bij eenzelfde nut, ${ }^{23}$ (iii) wanneer de door de rechtsuitoefening veroorzaakte schade buiten verhouding staat tot het voordeel dat de houder van het recht nastreeft of heeft verkregen, ${ }^{24}$ (iv) bij miskenning van het opgewekte rechtmatig vertrouwen $^{25}$ of (v) in strijd met de doelstelling van de rechtsbron waaruit het subjectief recht voortspruit. ${ }^{26}$

De abusieve rechtsuitoefening wordt gematigd tot de normale rechtsuitoefening door een bedachtzaam en voorzichtig persoon geplaatst in dezelfde omstandigheden of de veroorzaakte schade wordt hersteld. Het matigen van de gekozen rechtsuitoefening tot de normale rechtsuitoefening kan leiden tot het beperken of het ontzeggen van het recht. ${ }^{27}$

Doordat het verbod van rechtsmisbruik verduidelijkt dat het rechtssubject niet over een dermate verstrekkend subjectief recht beschikt, maar wel over een meer gematigd subjectief recht, ${ }^{28}$ is het evenwel preciezer om te stellen dat het rechtssubject de toepassing van een rechtsregel probeert in te roepen, in plaats van een subjectief recht heeft uitgeoefend (dat niet bestaat). De rechtsregel, de bron waaruit het subjectief recht voortspruit, kent immers geen subjectief recht toe dat op om het even welke wijze of in om het even welke omstandigheden kan worden

22 Zie bijv. Cass. 10 september 1971, Arr. Cass. 1972, 31-43, concl. W. Ganshof van der Meersch; RCJB 1976, 300, noot P. Van Ommeslaghe, Abus de droit, fraude aux droits des tiers et fraude à la loi.

23 Zie bijv. Cass. 6 januari 2011, AR C.09.0624.F; Cass. 16 november 1961, Arr.Cass. 1962, 269; Pas. 1962, I, 332; Cass. 12 juli 1917, Pas. 1918, I, 65.

24 Zie bijv. Cass. 3 februari 2017, AR C.16.0055.N; Cass. 19 maart 2015, AR C.13.0218.F; Cass. 6 januari 2011, AR C.09.0624.F; Pas. 2011, 44, concl. A. Henkes.

25 Cf. Cass. 1 oktober 2010, AR C.09.0565.N, RW 2011-12, 142, noot S.S. Jansen en S. Stijns, Rechtsverwerking aanvaard als toepassing van rechtsmisbruik?; Cass. 20 oktober 2006, RW 2008-09, 1661.

26 Zie bijv. Cass. 15 februari 2019, AR C.18.0428.N; Cass. 2 april 2015, AR C.14.0281.F; Cass. 7 september 2006, AR C.04.0032.F; Cass. 24 september 2001, AR S.00.0158.F; Cass. 28 april 1972, Arr.Cass. 1972, 815; Pas. 1972, 797; RW 1972-73, 217, noot R. Butzler. Het doelgebonden karakter vloeit niet noodzakelijkerwijze voort uit de wet (of de veronderstelde wil van de wetgever). Ook de rechter kan het toegekende recht verbinden aan een bepaalde doelstelling. Zie bijv. Cass. 13 januari 2012, AR C.11.0135.F. Vaak zal ook het rechtssubject dat een subjectief recht toekent, het recht doelgebonden hebben gemaakt. Een contractueel recht kan bijvoorbeeld doelgebonden zijn.

27 Zie bijv. Cass. 2 februari 2018, AR C.17.0386.F; Cass. 27 februari 2004, Res Jur.Imm. 2004, al. 3, 189; Cass. 8 februari 2001, C.98.0470.N; RW 2001-02, 778, noot A. Van Oevelen; Cass. 18 februari 1988, Arr.Cass. 1987-88, 790; Pas. 1988, I, 728. De werking van het verbod van rechtsmisbruik reikt niet verder dan nodig is om het misbruik te verhinderen of de schadelijke gevolgen te herstellen. Zie bijv. Cass. 19 oktober 2018, AR C.15.0086.N.

28 Bij misbruik van een contractueel recht, bestaat er een raakvlak tussen het verbod van rechtsmisbruik en het in art. 1134, lid 3 BW vervatte beginsel dat overeenkomsten te goeder trouw moeten worden uitgevoerd, in die zin dat een partij bij de uitoefening van een contractueel recht het beginsel van de uitvoering te goeder trouw van overeenkomsten slechts miskent wanneer is vastgesteld dat zij haar recht heeft misbruikt. Zie Cass. 13 maart 1998, AR C.97.0050.F; Cass. 17 mei 1990, Arr. Cass. 1989-90, 1188. 
uitgeoefend. ${ }^{29}$ Het feit dat scherpe feiten grenzen stellen - recht verfijnen ${ }^{30}$ wordt weliswaar vermomd door de uitlegging van de rechtsregel aan de hand van de veronderstelling dat de regelgever niet de bedoeling heeft om een subjectief recht toe te kennen wanneer de uitoefening ervan abusief is. ${ }^{31}$ Uiteindelijk wordt gewoonweg vereist dat er enigszins rekening wordt gehouden met de rechtmatige belangen van een ander. De achterliggende waarden en belangen moeten ten opzichte van elkaar worden afgewogen en de eindbalans mag niet disproportioneel overhellen. ${ }^{32}$

Wanneer een bemiddelaar zichzelf op een ongeoorloofde wijze probeert te verrijken door een overdreven bemiddelingsvergoeding te eisen, kan het verbod van rechtsmisbruik aldus verduidelijken dat de bemiddelaar slechts een meer gematigde bemiddelingsvergoeding kan opeisen of zelfs geen aanspraak kan maken op een bemiddelingsvergoeding. De rechter zal daarbij rekening houden met alle concrete omstandigheden, zoals de inspanningen die de bemiddelaar heeft ver-

29 De regelgever, die vermoed wordt redelijk te zijn, heeft niet de bedoeling om een subjectief recht toe te kennen wanneer de uitoefening ervan abusief is. Zie J. Velaers, Rechtsmisbruik: begrip, grondslag en legitimiteit, in: J. Rozie, S. Rutten \& A. Van Oevelen (eds.), Rechtsmisbruik, Antwerpen: Intersentia 2015, p. 1-28.

30 Zie bijv. J.B.M. Vranken, Algemeen deel in Mr. C. Asser's handleiding tot de beoefening van het Nederlands burgerlijk recht, Zwolle: W.E.J. Tjeenk Willink 1995, p. 57 e.v.; P. Scholten \& G.J. Scholten, Algemeen deel, in: Mr. C. Asser's handleiding tot de beoefening van het Nederlands burgerlijk recht, Zwolle: W.E.J. Tjeenk Willink 1974, p. 33 e.v.

31 Zie bijv. J. Velaers, Rechtsmisbruik: begrip, grondslag en legitimiteit, in: J. Rozie, S. Rutten \& A. Van Oevelen (eds.), Rechtsmisbruik, Antwerpen: Intersentia 2015, p. 1-28. Cf. K. Raes, Recht en ethiek in rechtstatelijk perspectief. Het leerstuk van het rechtsmisbruik en de eigenheid van rechtsbeginselen, in: Liber Amicorum Paul De Vroede, Diegem: Kluwer 1994, p. 1129-1162, waar wordt opgemerkt dat een onderscheid moet worden gemaakt tussen de doelstelling die aan de rechtsregel ten grondslag ligt en de doelstelling die de titularis heeft bij de rechtsuitoefening; V. Withofs, Bevoegdheden als categorie van subjectieve rechten: afbakening, kenmerken en juridisch regime, TPR 2016, (433) 457, waar wordt opgemerkt dat rechtsmisbruik niet uitgesloten is, wanneer het recht voor het toegekende doel wordt uitgeoefend. Het onderscheid tussen de doelstelling van de rechtsregel en de doelstelling van de rechtsuitoefening hangt evenwel af van de invulling die aan de doelstelling van de rechtsregel wordt gegeven. Over de mogelijkheden van teleologische interpretatie, zie bijv. M. Meirlaen, Teleologische interpretatie. Mogelijkheden en grenzen, NjW 2019, p. 494-508.

32 Zie bijv. W. van Gerven, Het beleid van de rechter, Antwerpen: Standaard Wetenschappelijke Uitgeverij 1973, waar wordt opgemerkt dat elke rechtsregel enige speelruimte bevat en aan elk rechtsconflict een belangenconflict en een waardenconflict ten grondslag ligt; concl. W. Ganshof van der Meersch bij Cass. 10 september 1971, Arr.Cass. 1972, 31-43. Veel hedendaagse maatschappelijke waarden en opvattingen (bijv. over wat redelijk en billijk is), worden opgewaardeerd tot algemene rechtsbeginselen (bijv. fraus omnia corrumpit, verbod van rechtsregelontduiking of verbod van rechtsmisbruik) om de mythe van de rechter als 'bouche de la loi' in stand te houden. Zie M. Van Hoecke, Rechtsregel en normdoel. Een afweging van onderliggende rechtsbeginselen', in: De norm achter de regel. Hommage aan Marcel, Deurne: Kluwer Rechtswetenschappen België 1995, p. 181, 191-206. 
richt, het bereikte resultaat en de rechtmatige belangen en verwachtingen van de partijen. ${ }^{33}$

\section{Rechtmatig belang}

Enkel een rechtmatig belang verdient rechtsbescherming. Zo stelt het Hof van Cassatie dat enkel de krenking van een rechtmatig belang tot een rechtsvordering kan leiden ${ }^{34}$ en voor schadeloosstelling in aanmerking komt. ${ }^{35}$

Of een (on)rechtmatig belang voorligt, hangt af van de vraag of de aanspraak of het verweer rechtstreeks of onrechtstreeks neerkomt op het doen ontstaan of in stand houden van een ongeoorloofde toestand. ${ }^{36}$ De eigenaar die bijvoorbeeld enkel het behoud eist van zijn villa waarvoor geen vergunning is afgeleverd en waarvan de afbraak wordt gevorderd, heeft volgens het Hof van Cassatie geen rechtmatig belang. ${ }^{37}$ De vraag naar de rechtmatigheid of de geoorloofdheid van een gedraging komt neer op de vraag of de gedraging in overeenstemming is met het recht. ${ }^{38}$

De misbruiktoets wordt vaak gebruikt bij het inkleuren van de (on)rechtmatigheid van het belang. Zo bevestigt het Hof van Cassatie dat er sprake is van rechtsmisbruik wanneer iemand in rechte de ontbinding van een vennootschap vordert om louter de positie van deze vennootschap in een arbitrageprocedure te wijzigen. Wie een vordering instelt moet overeenkomstig de artikelen 17 en 18 van het Gerechtelijk Wetboek een belang hebben. De vordering mag geen rechtsmis-

33 Misbruik vereist op zich geen kwade trouw, maar de aanwezigheid van kwade trouw kleurt wel in belangrijke mate de vraag naar misbruik. Zie bijv. Cass. 19 december 2019, AR C.19.0127.N; Cass. 19 februari 2010, AR C.09.0118.F - C.09.0132.F; Cass. 7 september 2006, AR C.04.0032.F; Cass. 10 september 1971, Arr. Cass. 1972, 31-43. Bemiddeling op zich kan ook door een partij worden misbruikt (bijv. als vertragingsmanoeuvre). In die zin stelt art. 23 van de Deontologische code dat de bemiddelaar de plicht heeft de bemiddeling te schorsen of te beëindigen indien hij van oordeel is dat de bemiddeling wordt aangewend voor oneigenlijke of onaangepaste doeleinden.

34 Zie bijv. Cass. 28 november 2013, AR C.13.0166.N; Cass. 2 maart 2006, AR C.05.0061.N.

35 Zie bijv. Cass. 3 oktober 1997, Arr.Cass. 1997, 921; Pas. 1997, I, 965. Het vereiste van een rechtmatig belang vindt aldus toepassing bij het beoordelen van de toelaatbaarheid en de grond van de zaak. Zie ook H. De Wulf, Ontbrekende of onregelmatige facturen - en meteen ook vragen bij de rol van artikel 17 Ger.W. en de relevantie van nemo auditur (noot onder Cass. 2 maart 2006), TBH 2007, p. 255-272, waar wordt gesteld dat er geen strikte scheiding is tussen de rechterlijke beoordeling van de ontvankelijkheid en de gegrondheid van de zaak en wordt gepleit om de problematiek van het rechtmatig belang zo veel mogelijk vanuit artikel $17 \mathrm{Ger}$.W. te benaderen. Zie bijv. Cass. 8 maart 2018, AR C.17.0390.N; Cass. 2 maart 2006, AR C.05.0061.N.

37 Zie bijv. Cass. 7 oktober 2003, AR P.03.0422.N.

38 Zie bijv. J. Ronse, Schade en schadeloosstelling in Algemene Practische Rechtsverzameling, I, Gent: E. Story-Scientia 1984, p. 39-42: 'De rechtmatigheid is immers een van de vage begrippen in het recht, die, mits het behoud van hun wezenlijke kern, met de gehele rechtsorde mee evolueren, evenals de begrippen die erdoor samengevat zijn: de geoorloofde oorzaak (art. 1108 en 1131 B.W), de openbare orde en de goede zeden (art. [2] en art. 1131 B.W.). Rechtmatig (wettig, légitime, licite), betekent niets anders dan hetgeen in overeenstemming is met het recht. In de praktijk wordt deze inhoud benaderd langs een marginale toetsing van wat - tijdsgebonden - in de rechtspraak strijdig is of niet conform aan een minimumvereiste aan redelijkheid, aan eerlijkheid en aan fatsoen, nodig om het samenleven in stand te kunnen houden.' 
bruik opleveren. ${ }^{39}$ Aan de hand van het verbod van rechtsmisbruik heeft het Hof van Cassatie ook verduidelijkt dat de eis of het verweer moet steunen op een afdoende en redelijk belang. Het eisen of het weigeren van het herstel van een erfdienstbaarheid, wat de afbraak van een goed kan impliceren, vereist zo een zekere belangenafweging. Bij deze belangenafweging stelt het Hof dat het opzettelijk karakter van het miskennen van een erfdienstbaarheid zwaar kan doorwegen. ${ }^{40}$

Wanneer uit de feiten kan worden afgeleid dat het opzet van de bemiddelaar er hoofdzakelijk in bestaat om zichzelf te verrijken ten koste van de partijen, heeft de bemiddelaar geen rechtmatig belang om een vergoeding te eisen. Dit is bijvoorbeeld het geval wanneer de bemiddelaar (on)rechtstreeks het conflict tussen partijen heeft gecreëerd of in stand houdt om hier munt uit te slaan. Het toekennen van een vergoeding zou dan het ongeoorloofd verrijkingsoogmerk verwezenlijken. ${ }^{41}$

\section{Fraus omnia corrumpit}

Het algemeen rechtsbeginsel fraus omnia corrumpit verduidelijkt dat de rechtsregel geen uitwerking mag verlenen aan het bedrog van het rechtssubject. De rechtsregel die uitwerking dreigt te verlenen aan het bedrog, dat wil zeggen 'kwaadwilligheid, opzettelijke misleiding en oneerlijkheid met de bedoeling om te schaden of winst te behalen', moet worden verfijnd. ${ }^{42}$ Het Hof van Cassatie verduidelijkt dat het algemeen rechtsbeginsel fraus omnia corrumpit '(...) strekt tot het tenietdoen van de rechtsgevolgen die uit een bedrieglijke gedraging voortvloeien. Deze werking reikt niet verder dan nodig is om te verhinderen dat het door bedrog beoogde doel wordt bereikt'. ${ }^{43}$ Opdat eenieder een leven kan leiden dat beantwoordt aan de menselijke waardigheid, voorziet bijvoorbeeld artikel 1, eerste lid van de OCMW-wet ${ }^{44}$ in het recht op maatschappelijke dienstverlening, ongeacht de vergissingen, de nalatigheid of de fout van de aanvrager. Het Hof van Cassatie verduidelijkt evenwel dat dit artikel 'niet inhoudt dat [het OCMW] steun dient te verlenen aan diegene die zich met bedrieglijk opzet van al zijn bestaansmiddelen

39 Cass. 2 april 2015, AR C.14.0281.F.

40 Cf. Cass. 6 januari 2006, AR C.04.0358.F; Cass. 17 mei 2002, AR C.01.0101.F; Cass. 14 november 1997, AR C.96.0375.F.

41 Het nastreven van winst is op zich niet onverenigbaar met het optreden als een onafhankelijk en onpartijdig bemiddelaar. Het kantelpunt ligt m.i. voor wanneer uit de feiten kan worden afgeleid dat de bedoeling van de bemiddelaar er net niet in bestaat om op een onafhankelijke en onpartijdige wijze de partijen te begeleiden tot de beste oplossing, maar wel hoofdzakelijk uit zijn optreden munt te slaan. Zie ook randnummer 5.

42 Zie bijv. Cass. 21 april 2016, AR C.14.0407.N; Cass. 15 februari 2016, AR S.15.0020.F; Cass. 16 november 2015, AR S.14.0097.F; Cass. 8 januari 2010, AR C.07.0303.F; Cass. 19 maart 2004, AR C.03.0114.F; Cass. 29 maart 2001, AR C.00.0231.F.

43 Cass. 3 oktober 2019, AR C.18.0438.N. Net zoals het algemeen rechtsbeginsel verbod van rechtsmisbruik de rechtsregel verfijnt die wordt ingeroepen om uitwerking te verlenen aan het misbruik, verfijnt dus ook het algemeen rechtsbeginsel fraus omnia corrumpit de rechtsregel die wordt ingeroepen om uitwerking te verlenen aan het bedrog. Bedrog kan m.i. als een vorm van misbruik worden beschouwd. In elk geval verhullen beide beginselen de appreciatievrijheid die de rechter zichzelf toemeet onder het mom van een teleologische interpretatie van de rechtsregel.

44 Organieke wet van 8 juli 1976 betreffende de openbare centra voor maatschappelijk welzijn, BS 5 augustus 1976. 
ontdoet teneinde aanspraak te kunnen maken op maatschappelijke dienstverlening'. ${ }^{45}$ Evenmin kan de bedrieger zich beroepen op de onzorgvuldigheid van het slachtoffer om een verdeling van aansprakelijkheid te verkrijgen die tot gevolg heeft dat de bedrieger een voordeel uit zijn bedrog behoudt. ${ }^{46}$ Het algemeen rechtsbeginsel fraus omnia corrumpit zal verbieden dat een rechtsregel uitwerking verleent aan het bedrieglijk verrijkingsoogmerk van de bemiddelaar. Bij een onzorgvuldig slachtoffer zal de bemiddelaar zich bijvoorbeeld niet kunnen beroepen op de verdeling van de aansprakelijkheid in de mate dat die verdeling tot gevolg heeft dat de bemiddelaar een voordeel uit zijn bedrog behoudt. Evenmin zal de bemiddelaar zich kunnen beroepen op de rechtspersoonlijkheid van de verbonden vennootschap die hij inschakelt of probeert tussen te plaatsen om zijn bedrieglijk verrijkingsoogmerk te verwezenlijken. ${ }^{47}$

\section{Wilsgebrek bedrog}

Het wilsgebrek bedrog bij de totstandkoming van een overeenkomst verwijst naar een kunstgreep van een partij om de andere partij de overeenkomst te laten sluiten en die er ook toe leidt dat zij de voorliggende overeenkomst sluit. ${ }^{48}$ De kunstgreep bestaat in het bewust verzwijgen van informatie ${ }^{49}$ of het opzettelijk meede-

45 Cass. 10 januari 2000, AR S.99.0044.N (landbouwer maakt zich bedrieglijk onvermogend om tussenkomst te verkrijgen voor de kosten van zijn rustoord).

46 Cf. Cass. 3 oktober 2019, AR C.18.0438.N; Cass. 21 december 2018, AR C.18.0154.N; Cass. 18 maart 2010, C.08.0502.N; Cass. 23 september 1977, Arr.Cass. 1978, concl. Krings. Bij de samenloop van bedrog en een onzorgvuldigheid van het slachtoffer moet m.i. worden aangenomen dat een verdeling van aansprakelijkheid toch mogelijk is in de mate dat de verdeling alle gevolgen van bedrog uitwist. Zie ook M. Meirlaen, Vormen en kleuren van bedrog (noot onder Cass. 21 december 2018), T.Not. 2019, (502) 513-516 en verwijzingen aldaar. Het Hof van Cassatie lijkt op 3 oktober 2019 (AR C.18.0438.N) alvast in die zin terug te komen op zijn rechtspraak.

47 Cf. Cass. 8 januari 2010, AR C.07.0303.F; Cass. 19 maart 2004, AR C.03.0114.F. Het algemeen rechtsbeginsel Fraus omnia corrumpit zou ook de openbare orde raken. Zie bijv. concl. A. Van Ingelgem bij Cass. 14 november 2014, AR C.14.0043.N; A. Lenaerts, Fraus omnia corrumpit in het privaatrecht. Autonome rechtsfiguur of miskend correctiemechanisme?, Brugge: die Keure 2013, p. 74-75. Fraus omnia corrumpit zal zich dan ook verzetten tegen de vraag tot homologatie van een bemiddelingsakkoord, in de mate dat dit bemiddelingsakkoord uitwerking dreigt te verlenen aan bedrog. Zie ook art. 1733, lid 2 Ger.W. De artikelen 1132 en 1133, $1^{\circ}$ van het Gerechtelijk Wetboek voorzien voorts in het buitengewoon rechtsmiddel van de herroeping van gewijsde indien er persoonlijk bedrog is geweest.

48 Art. 1109 en 1116, lid 1 BW. Het volstaat dat de kunstgreep toerekenbaar is aan de contractpartij. Zie bijv. Cass. 9 november 1987, Arr.Cass. 1987-88, 318; Pas. 1988, 298. Wanneer een bewust misleidende mededeling geen impact heeft of kan hebben op de beslissing tot contracteren, is er geen sprake van een wilsgebrek door dit bedrog.

49 Het bewust verzwijgen kwalificeren als een kunstgreep veronderstelt dat de bedrieger de plicht had om de achtergehouden informatie mee te delen, wat op zijn beurt impliceert dat de bedrieger de informatie kent en opzettelijk heeft achtergehouden. Zie bijv. Cass. 21 december 2018, AR C. 18.0154.N; Cass. 8 mei 2014, AR C.13.0022.N; Cass. 18 maart 2010, AR C.08.0502.N; Cass. 30 juni 2005, AR C.04.0523.F; Cass. 16 september 1999, AR C.97.0301.N. 
len van misleidende informatie. ${ }^{50}$ Het verstrekken of achterhouden van informatie heeft tot doel om in hoofde van de wederpartij een verkeerde voorstelling van zaken te creëren of in stand te houden en zo haar toestemming te verkrijgen tot het sluiten van de overeenkomst. ${ }^{51}$ Het bedrog vormt een wilsgebrek, omdat de wederpartij zonder de kunstgreep de voorliggende overeenkomst niet zou hebben gesloten.

Wanneer het wilsgebrek bedrog uit de feiten kan worden afgeleid, kan de bedrogene de (gedeeltelijke) nietigverklaring vorderen van de overeenkomst met of zonder een vergoeding van de schade die niet door de nietigheid en de daaruit voortvloeiende restitutieverbintenissen wordt hersteld, of alleen schadevergoeding omwille van de precontractuele fout. Een zorgvuldig persoon bedriegt de onderhandelingspartner niet. ${ }^{52}$

Aangezien de rechter uit de feiten afleidt of er een kunstgreep voorligt, welke invloed deze heeft uitgeoefend op de wil van de bedrogen partij en welke rechtmatige belangen moeten worden hersteld, zal de rechter nagaan of de sanctie die de partij vordert ook opportuun is om de rechtmatige belangen te herstellen, dan wel of een meer gematigde sanctie vereist is. ${ }^{53}$ Sancties moeten op maat worden gesneden en toegepast. ${ }^{54}$

In die zin wordt vaak gesleuteld aan de nietigheidssanctie en de daaruit voortvloeiende rechtsgevolgen. De rechtsfiguur van de partiële nietigheid illustreert zo dat de nietigheid slechts een deel van de overeenkomst(en) of een beding kan

50 M.i. kan ook het meedelen van juiste informatie neerkomen op bedrog, aangezien informatie op verschillende wijzen kan worden opgevat. Wanneer bijvoorbeeld wordt meegedeeld dat de woning een vergunning heeft, kan de vraag rijzen of de vergunning ook de aangebouwde veranda of garage vat. Desgevallend wordt aangevoerd dat de informatieverstrekker bedrieglijk heeft gezwegen en zo de wederpartij in een waan heeft gelaten. Cf. R. Van den Bergh, Misleidende juiste reclame, in: Liber Amicorum Paul De Vroede, Diegem: Kluwer 1994, p. 1343-1362.

51 Zie bijv. Cass. 21 mei 1953, Arr.Cass. 1953, 647; Pas. 1953, I, 731.

52 Art. 1109, 1116, 1117, 1382 en 1383 BW. Zie bijv. Cass. 23 november 2017, AR C.17.0389.N.

53 Zie bijv. Cass. 13 april 2018, AR C.17.0191.F; Cass. 12 februari 2015, AR C.14.0330.F; Cass. 18 februari 1999, AR C.97.0443.F. De rechter zal oordelen over de zwaarwichtigheid en de gevolgen van het bedrog en naargelang het geval de vernietiging met of zonder schadevergoeding toekennen, dan wel alleen schadevergoeding. Cf. concl. Krings bij Cass. 23 september 1977, Arr.Cass. 1978, 107-116.

54 Cf. Cass. 4 januari 2019, AR C.18.0045.N; Cass. 10 september 2018, AR C.18.0073.N; Cass. 23 november 2017, AR C.17.0389.N; Cass. 23 januari 2015, AR C.13.0579.N. Zie ook art. 5.60, lid 2 wetsvoorstel tot invoeging van boek 5 'Verbintenissen' in het nieuw Burgerlijk Wetboek, Parl.St. Kamer 2018-19, nr. 3709/1, 'Het contract blijft evenwel geldig in de gevallen die door de wet zijn bepaald of wanneer uit de omstandigheden blijkt dat de nietigheidssanctie kennelijk ongeschikt zou zijn, gelet op het doel van de geschonden regel.' 
treffen. ${ }^{55}$ Aan de hand van de rechtsspreuk In pari causa turpitudinis cessat repetitio kan de rechter ook de restitutie weigeren die voortspruit uit de terugwerkende kracht van de nietigverklaring, indien de restitutie niet bijdraagt tot de preventieve rol van de nietigheidssanctie of de maatschappelijke orde vereist dat een partij zwaarder wordt getroffen. ${ }^{56}$ Het algemeen rechtsbeginsel van het verbod van rechtsmisbruik kan volgens het Hof van Cassatie zelfs verduidelijken dat in welbepaalde omstandigheden de nietigheid niet meer kan worden geëist, ook al is de onderliggende miskende rechtsregel voorgeschreven op straffe van nietigheid. ${ }^{57}$ Zelfs de miskenning van een rechtsregel van openbare orde leidt volgens het Hof van Cassatie niet automatisch tot de absolute nietigheid. Daarbij verduidelijkt het Hof het volgende: 'Behoudens de wet zich hiertegen verzet, blijft de overeenkomst in stand indien de ongeoorloofdheid van de overeenkomst wordt of kan worden ongedaan gemaakt, derwijze dat het doel dat de wet beoogt, wordt of kan worden bereikt.' 58

Wanneer uit de feiten kan worden afgeleid dat de bemiddelaar zijn ongeoorloofd verrijkingsoogmerk heeft verzwegen, kan de bemiddelingsovereenkomst nietig worden verklaard. Een partij zou de bemiddelingsovereenkomst bijvoorbeeld niet hebben gesloten, indien zij op de hoogte was van het opzettelijk stilzwijgen van de bemiddelaar over het feit dat hij zich hoofdzakelijk via de bemiddeling wil verrijken.

Wanneer blijkt dat het bedrog toerekenbaar is aan één van de partijen, kan de overeenkomst die door de bemiddeling tot stand is gekomen, worden vernie-

55 Het maatwerk van de nietigheidssanctie hangt onder meer af van de wil van een partij, de gemeenschappelijke bedoeling van de partijen, de gerechtvaardigde belangen en verwachtingen van de partijen en de doelstelling van de rechtsregel waaruit de nietigheidssanctie voortvloeit. Cf. Cass. 4 januari 2019, AR C.18.0045.N; Cass. 10 september 2018, AR C.18.0073.N; Cass. 23 november 2017, AR C.17.0389.N; Cass. 25 juni 2015, AR C.15.008.F; Cass. 23 januari 2015, AR C.13.0579.N. Zie ook T. Tanghe, Gedeeltelijke ontbinding en vernietiging van overeenkomsten, Antwerpen: Intersentia 2015, p. 224 waar ervoor wordt gepleit om het onverbrekelijk verband te beoordelen vanuit de vraag of de gedeeltelijke instandhouding van de overeenkomst redelijkerwijze van een contractpartij kan worden verwacht.

56 Zie bijv. Cass. 15 februari 2016, AR C.14.0448.F; Cass. 24 september 1976, Arr.Cass. 1977, 98; Cass. 8 december 1966, Arr.Cass. 1967, 450. Voor enkele twistpunten en strekkingen over deze toverspreuk, zie bijv. I. Claeys, Nemo auditur en in pari causa: enkele twistpunten (noot onder Cass. 5 september 1996), Rec.Cass. 1997, 218-224.

57 Zie bijv. Cass. 24 juni 2010, AR C.09.0065.N. Zie ook C. De Wulf, De draagwijdte van het recente cassatiearrest in verband met de mededeling van het bodemattest (noot onder Cass. 24 juni 2010), T.Not. 2010, (575) 578; J. del Corral, Nietigheid als sanctie wegens miskenning van de informatieplicht van art. 101 Bodemdecreet: te pas en te onpas (noot onder Cass. 24 juni 2010), RW 2010-11, (1521) 1522-1525.

58 Cass. 7 november 2019, AR C.19.0061.N. Of de nietigheid bijdraagt tot de verwezenlijking van de doelstelling van de onderliggende miskende rechtsregel, hangt af van de inkleuring van de doelstelling. Naargelang het inkleuren van de veronderstelde doelstelling van de rechtsregel kan de draagwijdte van de nietigheidssanctie worden bijgesteld. Zie bijv. M. Meirlaen, Teleologische interpretatie. Mogelijkheden en grenzen, NjW 2019, p. 494-508, waar wordt geillustreerd hoe het Hof van Cassatie de doelstelling van een rechtsregel kan dateren, actualiseren, veralgemenen of concretiseren 
tigd. ${ }^{59}$ Neem bijvoorbeeld het geval waarin een man als bemiddelaar tussenkomt in een conflict tussen een buurvrouw en een projectontwikkelaar die op het aangrenzend perceel een winkelcomplex wil oprichten. De buurvrouw heeft beroep aangetekend tegen de vergunning tot het oprichten van het winkelcomplex. De projectontwikkelaar vreest dat hij het winkelcomplex zal kunnen opbergen. Om het conflict op te lossen komt een man als bemiddelaar tussen. Door de tussenkomst van de bemiddelaar koopt de projectontwikkelaar de woning van de buurvrouw tegen een hoge prijs. Vervolgens blijkt echter dat de bemiddelaar zelf de buurvrouw had aangezet om beroep aan te tekenen tegen de vergunning tot het oprichten van een winkelcomplex om louter de projectontwikkelaar onder druk te kunnen zetten en hieruit munt te slaan. Niet alleen de bemiddelingsovereenkomst zal nietig kunnen worden verklaard wegens bedrog, maar ook de koopovereenkomst tussen de projectontwikkelaar en de buurvrouw. ${ }^{60}$

\section{Ongeoorloofde oorzaak}

De oorzaak als geldigheidsvereiste peilt naar de achterliggende beweegreden(en) om een verbintenis aan te gaan - het waarom. In die zin stelt het Hof van Cassatie dat de oorzaak als geldigheidsvereiste van een verbintenis bestaat uit het geheel van de beweegredenen die de schuldenaar ertoe heeft aangezet de verbintenis aan te gaan. ${ }^{61}$ Bij de overeenkomst, een bron van verbintenissen, bestaat de

59 Het volstaat dat de kunstgreep toerekenbaar is aan de contractpartij. Cf. Cass. 9 november 1987, Arr.Cass. 1987-88, 318; Pas. 1988, 298.

60 Cf. Antwerpen 22 oktober 2019, nr. 2018/AR/1500 en 2018/AR/1503, onuitg. Op zich is er niets mis met een verrijkingsoogmerk. Het kantelpunt moet blijken uit scherpe feiten. In casu blijkt het ongeoorloofd verrijkingsoogmerk van de bemiddelaar (die een voormalig gemeenteraadslid is en persoonlijk failliet is verklaard) uit het verbergen van zijn hoedanigheid als werkelijke initiatiefnemer van de beroepsprocedure tegen de vergunning en uit het misbruik van de beroepsprocedure. Het beroep tegen de vergunning is er immers louter op gericht om hieruit munt te slaan - los van elke stedenbouwkundige finaliteit.

61 Zie bijv. Cass. 12 december 2008, AR 06.0332.N; Cass. 14 maart 2008, AR C.05.0380.F; Cass. 24 november 2007, AR C.06.0107.F. 
oorzaak dan ook in de doorslaggevende beweegreden(en) om de overeenkomst te sluiten. ${ }^{62}$

Aangezien de oorzaak volgens artikel 1133 van het Burgerlijk Wetboek ongeoorloofd is 'wanneer zij door de wet verboden is, of wanneer zij strijdig is met de goede zeden of met de openbare orde', is de vraag of de determinerende beweegreden in strijd is met het recht. De oorzaak als geldigheidsvereiste verhult louter een rechtstreekse toetsing aan het recht. Of de doorslaggevende beweegreden om een overeenkomst te sluiten ongeoorloofd is, hangt uiteindelijk af van de vraag of de overeenkomst tot gevolg heeft dat een ongeoorloofde toestand ontstaat of in stand wordt gehouden. ${ }^{63}$

Volgens het Hof van Cassatie volgt uit de artikelen 2, 1131 en 1133 van het Burgerlijk Wetboek dat een overeenkomst die een ongeoorloofde oorzaak heeft omdat zij door de wet is verboden of strijdig is met de openbare orde, geen gevolg kan hebben. Een rechtsvordering die strekt tot de uitvoering van een dergelijke overeenkomst kan niet worden toegelaten. De overeenkomst die een ongeoor-

62 Over de vraag of de determinerende beweegredenen gemeen moeten zijn aan alle partijen bestaat discussie. Daarbij rijst in essentie de vraag of het redelijk is een overeenkomst nietig te verklaren omdat een van de partijen bewogen werd door ongeoorloofde beweegredenen die aan de andere onbekend zijn. Zie bijv. art. 5.56 en MvT bij wetsvoorstel tot invoeging van boek 5 'Verbintenissen' in het nieuw Burgerlijk Wetboek, Parl.St. Kamer 2018-19, nr. 3709/1, 55-57 en 292. Terecht wordt in deze discussie opgemerkt dat de onschuldige partij wel de nietigverklaring moet kunnen vorderen, maar de nietigheid wegens een ongeoorloofd motief van een contractpartij zich niet zomaar mag keren tegen de onschuldige contractpartij. Zie I. Claeys, Nietigheid van contractuele verbintenissen in beweging, in: P. Arnou, B. Tilleman \& M. Boes (red.), Sancties en nietigheden, Brussel: Larcier 2003, p. 267, 276-283. Het Hof van Cassatie heeft tot nu toe enkel verduidelijkt dat 'het, als het algemeen belang in het geding is, voldoende is dat één van de partijen bij het sluiten van het contract ongeoorloofde oogmerken had en dat het niet nodig is dat de medecontractant daarvan op de hoogte is'. Zie Cass. 12 oktober 2000, AR C.99.9136.F. Recent verduidelijkt het Hof evenwel opnieuw dat '[d]e oorzaak van een overeenkomst bestaat uit de determinerende beweegredenen die elke partij ertoe hebben bewogen om de overeenkomst te sluiten en die gekend waren of behoorden te zijn aan de andere partij'. Zie Cass. 7 mei 2020, AR C.19.0423.N. Bij deze discussie mag in elk geval niet worden vergeten dat nietigheid steeds maatwerk vereist en het (eenzijdig) ongeoorloofd motief van een partij desgevallend via een andere weg kan worden beteugeld, zoals het wilsgebrek bedrog. Wanneer het ongeoorloofd motief pas ontstaat in de uitvoeringsfase van de overeenkomst, kan een beroep worden gedaan op de miskenning van de verplichting om de overeenkomst te goeder trouw uit te voeren (de misbruiktoets, zoals vervat in art. 1134, lid 3 BW).

63 Veel (om)wegen, via open normen, verduidelijken uiteindelijk dat de ongeoorloofdheid van de gedraging afhangt van de vraag of de gedraging een rechtsregel miskent of zou miskennen. Of dit het geval is, wordt beoordeeld aan de hand van andere open normen, zoals de openbare orde of algemene rechtsbeginselen. Dit geldt ook voor het geldigheidsvereiste van een geoorloofd voorwerp. Volgens het Hof van Cassatie heeft een overeenkomst een ongeoorloofd voorwerp wanneer zij 'ertoe strekt een toestand te doen ontstaan of in stand te houden die in strijd is met de openbare orde of met dwingende wetsbepalingen'. Zie bijv. Cass. 8 maart 2018, AR C.17.0390.N. Een overeenkomst heeft rechtsgevolgen tot voorwerp. Zie ook MvT bij wetsvoorstel tot invoeging van boek 5 'Verbintenissen' in het nieuw Burgerlijk Wetboek, Parl.St. Kamer 2018-19, nr. 3709/001, 53. 
loofde oorzaak heeft is nietig. ${ }^{64}$ De nietigheidssanctie vereist weliswaar maatwerk (zie randnummer 15).

Wanneer uit de feiten kan worden afgeleid dat de doorslaggevende beweegreden van de bemiddelaar erin bestaat om zichzelf te kunnen verrijken, kan de bemiddelingsovereenkomst nietig worden verklaard. Dit zal bijvoorbeeld het geval zijn wanneer de bemiddelaar (on)rechtstreeks heeft bijgedragen tot het conflict tussen partijen om hieruit munt te slaan. ${ }^{65}$

\section{Conclusie: variaties om ongeoorloofde verrijking te verhinderen}

De bemiddelaar moet aldus op een onafhankelijke en onpartijdige wijze bemiddelen. Over elk mogelijk gebrek aan onafhankelijkheid of onpartijdigheid moet de bemiddelaar de partijen informeren. Wanneer de bemiddelaar zijn ongeoorloofd verrijkingsoogmerk verzwijgt, biedt vooral het verbintenissenrecht de nodige correctiemechanismen. De bemiddelingsovereenkomst kan nietig worden verklaard wegens het wilsgebrek bedrog of de ongeoorloofde oorzaak. In dezelfde zin kan het bedrieglijk opzet van één van de partijen er ook toe leiden dat de overeenkomst die door de bemiddeling tot stand is gekomen nietig wordt verklaard. De overeengekomen bemiddelingsvergoeding kan worden gematigd, zelfs ontzegd, aan de hand van het algemeen rechtsbeginsel verbod van rechtsmisbruik. Fraus omnia corrumpit verhindert dat de bemiddelaar de toepassing van een rechtsregel kan genieten die hem toelaat om zijn bedrieglijk oogmerk te verwezenlijken of een voordeel uit zijn bedrog te behouden. De bemiddelaar zal zijn ongeoorloofd verrijkingsoogmerk niet kunnen verschuilen achter de rechtspersoonlijkheid van zijn schermvennootschap. Evenmin zal de bemiddelaar zich kunnen beroepen op de onzorgvuldigheid van het slachtoffer om een verdeling van aansprakelijkheid te verkrijgen en zo een voordeel uit zijn bedrog te behouden. De bemiddelaar zal zijn eis of verweer gewoonweg niet kunnen steunen op een rechtmatig belang. Al deze correctiemechanismen vormen uiteindelijk slechts variaties van eenzelfde streven naar gezond verstand en gerechtigheid. ${ }^{66}$ Het recht mag er niet toe leiden dat een bedrieglijk oogmerk wordt verwezenlijkt. Het hoofddoel van de bemiddelaar moet er immers in bestaan om partijen op een onafhankelijke en onpartijdige wijze tot een oplossing te brengen.

64 Zie bijv. Cass. 10 september 2018, AR C.17.0113.N; Cass. 29 september 2008, AR C.06.0443.F. Doordat de overeenkomst met een ongeoorloofde oorzaak geen gevolg kan hebben, is de verrijking van degene die er de uitvoering van geniet zonder oorzaak. Zie bijv. Cass. 15 februari 2016, AR C.14.0448.F.

65 Cf. Antwerpen 22 oktober 2019, nr. 2018/AR/1500 en 2018/AR/1503, onuitg.

66 Cf. Cass. 15 mei 1930, Pas. 1930, I, 223, waarbij het kopje van het arrest als volgt luidt: 'Quand une disposition légale est susceptible d'être comprise comme décidant ce que la saine raison et le sentiment naturel du juste commandent de décider, elle doit être interprétée en ce sens.'; Cass. 9 februari 1925, Pas. 1925, I, (129) 142 '[...] il convient parfois de rechercher ce qu'a voulu dire le législateur, plutôt que ce qu'il a dit littéralement; qu'il est préférable, en principe, de supposer qu'il a employé une expression traduisant imparfaitement sa pensée issue de l'arbitraire.' 